\title{
5.5. ФИНАНСОВАЯ УСТОЙЧИВОСТЬ БАНКОВ: ЗАРУБЕЖНЫЕ И РОССИЙСКИЕ ПОДХОДЫ К ОЦЕНКЕ
}

Морозов А.В., аспирант, Экономический фракультет, кафедра «Учет, анализ и аудит»

\author{
Московский государственный университет им. М.В. Ломоносова, г. Москва
}

В статье рассмотрены подходы международных и национальных надзорных органов к оценке финансовой устойчивости банков и банковского сектора. Автором показано, что подходы международных надзорных органов базируются на сочетании микропруденциального и макропруденциального анализа и включают комплексную оценку основных фринансовых показателей и банковских рисков. Подходы Центрального банка РФ опираются на международный опыт и направлены на обеспечение устойчивости банков к системным рискам в фринансовом секторе экономики.

\section{Литература}

1. Об оценке финансовой устойчивости банка в целях признания ее достаточной для участия в системе страховых вкладов [Электронный ресурс] : указание Центрального банка РФ от 11 июня 2014 г. №3277-У. Доступ из справ.правовой системы «Консультант Плюс».

2. Об оценке экономического положения банков [Электронный ресурс] : указание Центрального банка РФ от 3 апр. 2017 г. №4336-У. Доступ из справ.-правовой системы «Консультант Плюс».

3. Банковское дело [Текст] : учеб. / под ред. О.И. Лаврушина. - 12-е изд., стер. - М. : КНОРУС, 2016. - 800 с.

4. Данилова Е.О. Макропруденциальная политика: теоретические аспекты и практический опыт Банка России [Текст] / Е.О. Данилова, Н.Б. Елизарова // Деньги и кредит. - 2017. - №6. - С. 5-17.

5. Иванов В.В. Анализ надежности банка [Текст] / В.В. Иванов. - М. : Русская деловая лит-ра, 1996. -320 с.

6. Информация о банковской системе Российской Федерации [Электронный ресурс] // Центральный банк РФ : официальный сайт. - Режим доступа: www.cbr.ru

7. Оценка финансовой устойчивости кредитной организации [Текст] : учеб. / ред. О.И. Лаврушин, И.Д. Мамонова. - 2-е изд., стереотип. - М. : КНОРУС, 2013. - 304 с.

8. Российский научно-технический центр информации по стандартизации, метрологии и оценке соответствия [Электронный pecypc]. - URL : http:// www.gostinfo.ru/ pages/Catalogs/

9. Устойчивость банковской системы и развитие банковской политики [Текст] / под ред. О.И. Лаврушина. - М. : КНОРУС, 2014. $-280 \mathrm{c}$.

10. Фетисов Г.Г. Устойчивость коммерческого банка и рейтинговые системы ее оценки [Текст] / Г.Г. Фетисов. - М. : Финансы и статистика, 1999. - 167 с.

11. Шеремет А.Д. Комплексный анализ показателей устойчивого развития предприятия [Текст] / А.Д. Шеремет // Экономический анализ: теория и практика. - 2014. - Т. 45; №326. - С. 2-10.

12. Basel III: A global regulatory framework for more resilient banks and banking systems. Basle. December 2010 [Электронный pecypc] / URL: www.bis.org/publ/bcbs189.pdf

13. Enhancing financial stability and resilience: macroprudential policy, tools, and systems for the future. Group of Thirty. Washington. 2010 [Electronic resource]. - URL : www.group30.org/images/uploads/publications/G30

14. IMF-FSB-BIS. Elements of Effective Makroprudential Policies. Lessons from International Experience. 31 August. 2016. [Electronic resource]/ - URL : www.imf.org/exernal/np/g20/pdf/2016/083116.pdf

15. International convergence of capital measurement and capital standards. Basel I [Electronic resource]. - Basle, July 1988. URL : www.bis.org

16. International convergence of capital measurement and capital standards. Basel II [Electronic resource]. Basle, June 2004. URL : www.bis.org/publ/bcbs $128 . h t m$

17. Modifications to the current list of financial soundness indicators (FSIs) [Electronic resource] // IMF policy paper. - Nov. 13, 2013. URL : www.imf.org/external/np/pp/eng/

18. 2013/111313.pdf

19. Principles for the manegement of credit risk [Electronic resource] // Consultative paper issued by the Basle. - Sept. 2000. URL : www.bis.org/publ/bcbs54.htm

20. Principles for sound liquidity risk management and supervision [Electronic resource]. - Basle, sept. 2008. - URL : www.bis.org/publ/bcbs144.htm

21. San-Jose A. Financial soundness indicators (FSIs) framework and implementation [Electronic resource] / A. San-Jose, A. Georgio // IFC bulletin. - 2009. - URL : www.bis.org/ifc/publ/ifcb31v.pdf

22. Gersl A., Hermanek G. Financial Stability Indicators: advantages and disadvantages of their use in the assessment of financial system stability. CNB Financial Stability Report. 2006. - URL: www.cnd.cz/en/financial_stability reports/fsr.article.

\section{Ключевые слова}

Банки; финансовая устойчивость; банковский надзор; риски; финансовые показатели; макропруденциальные инструменты; микропруденциальный анализ; Центральный банк РФ; Базель III; рейтинги.

\section{Морозов Антон Владимирович}

\section{РЕЦЕНЗИЯ}

Банковский сектор играет ключевую роль в распределении финансовых ресурсов и поэтому оказывает существенное влияние на темпы экономического роста и развитие экономики на микро- и макроэкономическом уровне. В связи с этим проблема обеспечения финансовой устойчивости банков является актуальной проблемой, как для международных, так и для национальных надзорных органов. 
Исследование автора направлено на анализ подходов к определению финансовой устойчивости банков и банковского сектора. В качестве примеров рассматриваются международный и национальный опыты банковского надзора, включая деятельность Центрального банка РФ (ЦБ РФ).

Проведенные исследования показывают, что разработка международных стандартов финансовой устойчивости обусловлена глобализацией мировой экономики и финансовых рынков. В то же время существует проблема в сопоставимости международных и национальных показателей финансовой устойчивости банков, что затрудняет анализ эффективности деятельности мировой финансовой системы. Национальные подходы к оценке финансовой устойчивости банковского сектора разнообразны и базируются преимущественно на риск-ориентированном подходе и оценке финансовых показателей, характеризующих деятельность банка. Однако после глобального международного финансового кризиса 2007-2009 гг. широкое развитие получила политика макропруденциального регулирования, направленная на повышение устойчивости банковского сектора к финансовым кризисам и системным рискам. Подходы ЦБ РФ опираются на международный опыт и направлены на обеспечение устойчивости отечественных банков к глобальным финансовым рискам.

Статья отличается последовательностью изложения, аргументированностью авторской позиции и может быть рекомендована к публикации. С учетом проблем устойчивости банковского сектора в РФ она является особенно актуальной.

Суйц В.П., д.э.н., заслуженный профессор Московского государственного университета, заведующий кафедрой учета, анализа и аудита, Московский государственный университет им. М.В. Ломоносова, г. Москва.

DOI 10.38097/AFA.2020.71.59.014 